\title{
Assessing plant-to-plant communication and induced resistance in sagebrush using the sagebrush specialist Trirhabda pilosa
}

\author{
Patrick Grof-Tisza ${ }^{1}\left[\right.$ D $\cdot$ Richard Karban ${ }^{2} \cdot$ Vincent S. Pan ${ }^{2} \cdot$ James D. Blande ${ }^{1}$
}

Received: 17 September 2019 / Accepted: 4 March 2020 / Published online: 12 March 2020

(c) The Author(s) 2020

\begin{abstract}
Plants respond to damage by herbivores or to reliable cues of damage by changing in ways that provide greater resistance and increase their fitness. Sagebrush has been a model system for understanding induced resistance, although resistance in this system is commonly assessed by quantifying damage at the end of the season; this measure is slow and lacks accuracy and interpretability because so many other factors also affect levels of damage. Herbivore choice offers a potentially rapid and accurate alternative assay of induced resistance. Here we evaluate whether feeding behavior of a specialized Chrysomelid beetle, Trirhabda pilosa, could be used to assay induced changes in plant quality. Beetle larvae were offered the choice between two leaves in Petri dish arenas. We found that beetles avoided leaves that were naturally damaged by herbivores, experimentally clipped with scissors, and exposed to the volatiles from naturally or experimentally damaged neighboring leaves compared to control leaves. Experiments varied the source of the damage, the duration of the feeding test, and how damage was measured, still, beetles consistently preferred uninduced controls by a 2:1 ratio over leaves exposed to cues of damage. These results suggest that behavioral assays using $T$. pilosa larvae can be used to rapidly evaluate induced resistance in this system. More generally, movement and feeding behaviors of herbivores are an important and underappreciated component of induced plant responses.
\end{abstract}

Keywords Artemisia tridentata $\cdot$ Behavioral bioassay $\cdot$ Plant-insect interactions $\cdot$ Trirhabda pilosa $\cdot$ Volatile-mediated communication $\cdot$ Volatile organic compounds

\section{Introduction}

Plants exhibit numerous responses when attacked by herbivores, many of which render them less susceptible to subsequent herbivore exploitation (i.e., induced resistance; Karban and Baldwin 1997). In addition to a direct attack, plants can respond to indirect cues such as volatile organic compounds (VOCs) emitted from their own tissues or those of damaged neighbors (Heil and Karban 2010). While induced resistance resulting from either direct damage or exposure

Handling Editor: Anna-Karin Borg-Karlson.

Patrick Grof-Tisza

p.groftisza@gmail.com

1 Department of Environmental and Biological Sciences, University of Eastern Finland, P.O. Box 1627, 70211 Kuopio, Finland

2 Department of Entomology and Nematology, University of California, 1 Shields Ave., Davis, CA 95616, USA to volatiles from damaged neighbors has been reported in numerous taxa (Karban and Baldwin 1997; Karban et al. 2014), most research has focused on just a few model systems (e.g., wild tobacco, goldenrod, lima bean). Detecting induced resistance and volatile-mediated communication poses several challenges for researchers, and reliable bioassays allow a quick and accurate assessment that plants have responded in biologically meaningful ways.

Assays used to study plant communication and induced resistance generally focus on indirect measures of plant responses such as herbivore survival, performance, and preference. More direct measures of plant responses include gene expression (and translated gene products), secondary metabolites and enzymatic activity, and VOC emissions thought to negatively affect or deter their herbivores (Kant et al. 2015). The standard experimental approach for studying induced resistance entails conducting one or several of these assays on tissue from plants that have been directly damaged or have been exposed to headspace VOCs emitted from damaged plants. However, the context of how damage 
is inflicted has strong effects on how plants respond; the timing, location, extent, source, (i.e., herbivore versus artificial damage) and herbivore identity can all affect plant responses, and consequently indirectly affect herbivores (War et al. 2012). Therefore, designing meaningful assays and determining appropriate experimental conditions can be a critical step in understanding induced resistance.

Caging herbivores on plants is a common approach to evaluate induced resistance. Indeed, many researchers have demonstrated that herbivores caged on damaged plants (Karban and Baldwin 1997) or plants previously exposed to headspace VOCs performed worse than those on control plants (Karban et al. 2014). While relying on natural patterns of herbivory as indicators of induced resistance may seem like an attractive and tractable alternative, the patchiness of herbivores in space and time may lead to erroneous findings or an inability to make strong inferences due to low sample sizes. Many other factors affect natural patterns of herbivory and these patterns generally require long time frames to develop.

Herbivore choice and other behaviors are often not considered when evaluating potential induced plant defenses, although they may be more sensitive and better measures of the consequences of induced responses compared to more commonly used measures of plant or herbivore performance. For example, hornworm caterpillars moved away from induced tobacco plants, although they did not experience a measurable decrease in performance on those tissues (Van Dam et al. 2001). Similarly, Trirhabda virgata larvae avoided damaged leaves of goldenrod, although they performed equally well on damaged and undamaged leaves (Uesugi et al. 2013). Many of the bioassays of herbivore performance cage and thereby constrain the focal herbivore's movement, which can lead to erroneous conclusions. Induced responses are often quite localized (Karban 2011) and damage-induced VOCs can locally adhere to the surface of leaves (Choh et al. 2004; Himanen et al. 2010), or be absorbed and locally converted into toxins (Sugimoto et al. 2014). Mobile herbivores in nature may avoid these localized responses.

Sagebrush has played an integral role in our understanding of induced resistance and volatile-mediated communication. In a seminal lab experiment, Farmer and Ryan (1990) took advantage of the high levels of the plant hormone methyl jasmonate emitted by sagebrush to induce elevated defenses in tomato plants incubated with cut sagebrush branches. Experimentally damaged sagebrush plants in the field caused neighboring tobacco plants to increase their defenses and to receive less natural damage from herbivores over their lifespans (Karban et al. 2000). Despite decades of studies on this system, no biological assays have been developed to rapidly assess communication and induced defenses in sagebrush; observing natural patterns of herbivory and plant damage are still the primary means to assess induced responses for this species. To this end, here we describe and assess the use of a sagebrush specialist leaf beetle, Trirhabda pilosa [Coleoptera, Chrysomelidae], as a means of developing a reliable behavioral bioassay. We were specifically interested in determining if $T$. pilosa would consistently distinguish between control leaves and leaves that were directly damaged either (1) artificially or (2) by other T. pilosa individuals. We also tested whether beetles would distinguish between control leaves and leaves exposed to headspace volatiles from (3) damaged tissues of the same plant or 4) other sagebrush individuals.

\section{Methods}

\section{Study system}

Sagebrush dominates the landscape of the Great Basin in the North American west (Young et al. 1988). It is widely exploited by an extensive list of vertebrate and invertebrate herbivores (Wiens et al. 1991). Previous studies demonstrated that sagebrush exhibited induced resistance when directly damaged or exposed to damage associated VOCs as measured by total herbivore damage accumulated over the growing season (Karban et al. 2006).

Trirhabda pilosa is a sagebrush specialist that is patchily distributed but often exists in high densities when present (Pringle 1960). In the Sierra Nevada mountains, T. pilosa larvae become conspicuous a few weeks after snowmelt and voraciously skeletonize sagebrush leaves (per obs). Adults emerge in mid to late summer, depending on elevation, and are commonly found eating flower buds. Females lay eggs at the base of the plant, where eggs overwinter, in outbreak years, $T$. pilosa larvae can almost defoliate entire stands of sagebrush (Pringle 1960). The closely related species, Trirhabda virgata has been used in bioassays to assess induced resistance in goldenrod (Solidago spp; Uesugi et al. 2013).

\section{Experimental design}

We performed several experiments to assess the potential of using $T$. pilosa larvae as a biological indicator of induced defenses resulting from direct damage or volatile-mediated communication from the same or different plants. While all experiments were conducted as choice tests with individual T. pilosa beetle larvae in Petri dishes, the experiments varied with regard to treatments, duration, and how preference was determined (e.g., first leaf attacked, biomass consumed). In the next paragraph, we describe the basic design of the choice tests, with the following sections and Table 1 providing the specific details for each experiment. 
Table 1 Characteristics of the six experiments testing preferences of beetles for sagebrush leaves receiving different treatments of herbivore damage or damage cues

\begin{tabular}{|c|c|c|c|c|c|c|c|}
\hline $\operatorname{Expt}^{\mathrm{a}}$ & Treat 1 & Source of damage & Treat 2 & Duration of expt & Measure of choice & Beetles tested & $\begin{array}{l}\text { Beetles } \\
\text { choos- } \\
\text { ing }\end{array}$ \\
\hline A & Natural damage & Herbivores & Undam. control & $1 \mathrm{~h}$ & $\begin{array}{l}\text { Arrested movement or } \\
\text { feeding }\end{array}$ & 50 & 32 \\
\hline B & Natural damage & Herbivores & Undam. control & Up to $8 \mathrm{~h}$ & $\begin{array}{l}\text { Arrested movement or } \\
\text { feeding }\end{array}$ & 40 & 35 \\
\hline $\mathrm{C}$ & Experimental damage & Scissors & Undam. control & Up to $8 \mathrm{~h}$ & $\begin{array}{l}\text { Arrested movement or } \\
\text { feeding }\end{array}$ & 40 & 31 \\
\hline D & $\begin{array}{l}\text { Nat. damage to neigh- } \\
\text { boring lvs on branch }\end{array}$ & Herbivores & Undam. control & Up to $8 \mathrm{~h}$ & $\begin{array}{l}\text { Arrested movement or } \\
\text { feeding }\end{array}$ & 40 & 29 \\
\hline $\mathrm{E}$ & $\begin{array}{l}\text { Exp. damage to neigh- } \\
\text { boring lvs on branch }\end{array}$ & Scissors & Undam. control & Up to $8 \mathrm{~h}$ & $\begin{array}{l}\text { Arrested movement or } \\
\text { feeding }\end{array}$ & 40 & 25 \\
\hline $\mathrm{F}$ & $\begin{array}{l}\text { Air from exp. damaged } \\
\text { neighbor lvs }\end{array}$ & Scissors & $\begin{array}{l}\text { Air from undam. } \\
\text { control }\end{array}$ & $1 \mathrm{~h}$ & $\begin{array}{l}\text { Leaf biomass con- } \\
\text { sumed }\end{array}$ & 34 & 30 \\
\hline
\end{tabular}

${ }^{a}$ Letters identifying experiments correspond to results presented in Fig. 1

All experiments were conducted in $100 \times 15 \mathrm{~mm}$ Petri dishes under laboratory conditions. One beetle larva was presented with leaves representing different treatments, which were randomly assigned to either side of the Petri dish. Beetles were collected from A. tridentata vaseyana plants from one population near the summit of Mt. Rose in Washoe County, Nevada (39 $\left.18^{\prime} 12.1^{\prime} \mathrm{N},-119^{\circ} 55^{\prime} 04.1^{\prime \prime}\right)$ and kept in a refrigerator at $5{ }^{\circ} \mathrm{C}$ prior to use. Binomial exact tests were used to determine statistical significance of preference.

\section{Preference for naturally damaged or undamaged leaves}

We conducted two experiments that compared the preferences of beetles for leaves that had been previously damaged by beetle feeding and those that had not been damaged. Branches from plants from Mt. Rose were removed and brought indoors. Leaves were haphazardly selected from these branches. Undamaged leaves were selected from branches that had no visible signs of beetle feeding. Fifty beetles that had been starved for $24 \mathrm{~h}$ were placed individually in Petri dishes containing one damaged leaf and one undamaged leaf. After one hour, the leaves in each Petri dish were evaluated for new feeding damage. The most damaged leaf was recorded. Beetles that did not feed and its corresponding trial were omitted from the study. A second choice test was conducted using forty beetles as described above. To increase our sample size in this experiment, we observed the beetles for up to eight hours, until they began feeding on one of the two leaves. Once feeding commenced, we recorded their choice and did not consider them further. As before, beetles that did not feed during this time period were removed from the study.

\section{Preference for experimentally damaged or undamaged leaves}

It is possible that leaves that were chosen by beetles differed from undamaged leaves that were not chosen in many characters, independent of previous damage history. We conducted an experiment that compared the preferences of beetles for randomly selected leaves that had been previously damaged by clipping the leaf tip with scissors, while the leaf was attached to the plant. This clipped leaf and an unclipped control on the same branch were offered to beetle larvae in Petri dishes $24 \mathrm{~h}$ after imposing the treatments as described above. Forty beetles that had been starved overnight were used in this experiment. We observed the beetles and considered them to have chosen a leaf if they stopped moving and began feeding as described above.

\section{Preference for leaves receiving volatile cues of damage versus controls}

Undamaged leaves may receive volatile cues from nearby damaged leaves and induce resistance. In order to test this plant communication hypothesis, we conducted three experiments. In the first experiment, forty beetle larvae were presented with undamaged leaves from two different branches. One of these undamaged leaves came from a branch that had been naturally attacked and damaged by chewing herbivores (grasshoppers or beetles). In other words, neighboring leaves on this branch had been selected by natural herbivores. The other, undamaged leaf came from a branch from the same plant with no apparent natural damage by herbivores. Preference was evaluated as described for the previous experiment.

In a second test, we repeated this comparison using undamaged leaves from two branches. For one of the two 
branches, one neighboring leaf had been clipped with scissors $24 \mathrm{~h}$ earlier and on the other branch no leaves had any signs of chewing damage. Preference was evaluated as described for the previous experiments.

We conducted a third experiment in which we inoculated branches with volatile cues from experimentally damaged neighbors. We haphazardly selected three branches on thirty focal plants at our field site to assess induced resistance in response to VOC cues. These three receiver branches were incubated with air from either the surrounding atmosphere (control) or from a branch from an experimentally damaged sagebrush plant (different than itself).

To generate volatile cues, we experimentally clipped with scissors the distal end of $25 \%$ of leaves on emitter branches that were used as sources of cues. Following clipping, each clipped branch was immediately enclosed in a plastic bag to collect headspace volatiles. A wire-twist tie was used to seal the bag to the stem. Previous work with sagebrush demonstrated that there were no measurable differences in induced resistance between receiver branches exposed to volatiles from neighboring sagebrush plants damaged in this way with scissors versus chewing herbivores (Shiojiri and Karban 2008). After $24 \mathrm{~h}$ of accumulating in the bag, headspace volatiles were transferred from the sealed bags enclosing the emitter branch into a bag enclosing receiver branches using a 1-L syringe (model s-1000; Hamilton, Reno, NV). Sagebrush branches are poorly connected by vascular tissue and are generally considered as independent (Karban et al. 2006), similar to many other plants (Herrera 2009). All receiver branches were then incubated with the transferred or ambient air (controls) for $24 \mathrm{~h}$. After $24 \mathrm{~h}$, bags were removed from receiver branches. After an additional $48 \mathrm{~h}$, each branch was cut with clippers and placed in a Ziplock bag and stored at $5{ }^{\circ} \mathrm{C}$ for less than 1 week until it was used in a choice test.

Preferences were determined by offering beetle larvae leaves from a subset of randomly chosen branches that had been exposed to volatile cues in the field and those that had not (controls). We calculated the biomass of leaf tissue consumed by beetle larvae in Petri dishes after $1 \mathrm{~h}$. All leaves were weighed before being placed in Petri dishes and after the beetles had access to them.

\section{Results}

\section{Preference for naturally damaged or undamaged leaves}

Beetles chose leaves that had not been damaged in preference to those that had been fed upon previously. In the first experiment, this preference was not statistically significant (Fig. 1A; binomial test $P=0.11$ ), but in the second

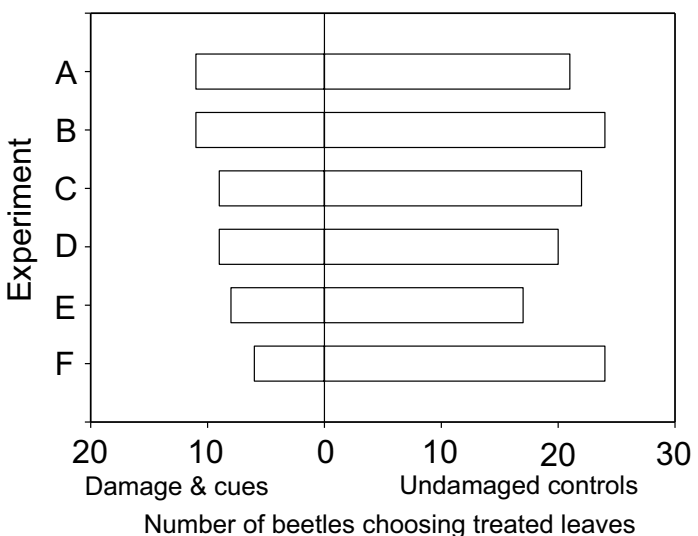

Fig. 1 The number of beetles that chose leaves that had been damaged or exposed to cues of damage versus control leaves. The letters indicate six different experiments that are described in the text and in Table 1

experiment beetle preference was in a similar direction and was significant (Fig. 1B; binomial test $P=0.04$ ).

\section{Preference for experimentally damaged or undamaged leaves}

As in the previous trials, beetle larvae preferred to eat leaves that had not been experimentally clipped, and this preference was statistically significant (Fig. $1 \mathrm{C}$; binomial test $P=0.01$ ).

\section{Preference for leaves receiving volatile cues of damage versus controls}

Beetle larvae preferred to feed on undamaged leaves that were not on branches that had been naturally damaged, although this result was only marginally significant (Fig. 1D; binomial test $P=0.06$ ).

More beetle larvae chose to feed on undamaged leaves on branches with no chewing damage compared to undamaged leaves on branches with one clipped leaf. However, this trend was not statistically significant (Fig. 1E, binomial test $P=0.11$ ).

Beetle larvae showed a strong preference for leaves that were incubated with ambient air (control leaves) as opposed to those incubated with VOCs collected from damaged branches (Fig. 1F, binomial test; $P=0.001$ ).

\section{Discussion}

In all the experiments that we conducted, beetle larvae preferred to feed on leaves that were undamaged compared to those that had received natural herbivory, experimental clipping, or were exposed to the VOCs from damaged branches 
(Fig. 1). This result was remarkably consistent even as the experiments differed in the source of the damage cue, the duration of the experiment, or how we quantified beetle choice (Table 1). This result was consistent if plants were selected by herbivores (experiments A, B), assigned randomly to be experimentally clipped with scissors (experiment C), or exposed to VOCs from damaged leaves (experiments D, E, F). In all cases, preference for undamaged leaves over damaged leaves or those exposed to volatile cues of damage was approximately 2:1 (Fig. 1).

The results of this study demonstrate the viability of using the leaf beetle, T. pilosa, as a bioindicator of induced resistance and volatile-mediated communication in A. tridentata vaseyana. Though induced resistance caused by direct damage and that resulting from exposure to volatiles emitted from neighboring plants is well established in sagebrush (Karban et al. 2006), this is the first description of an indirect bioassay to detect responses in this system. Using beetles as a bioassay has several advantages over measuring damage to branches at the end of the season (the bioassay method currently used in this system). The beetle assay is quicker, reliable, and produced a consistent and relatively large effect size.

In general, insect behavior is an excellent assay of induced defense, and one that has been underappreciated (Karban 2011; Rubin et al. 2015). It is more common for researchers to assess herbivore growth or survival although these measures often provide a misleading impression of the consequences of herbivory from the point of view of the plant. An herbivore that feeds on less nutritious plant tissues may compensate and consume more of it. Similarly, an herbivorous insect that attracts a parasitoid continues to feed. Both of these outcomes may reduce plant fitness more than a situation in which induced responses fail to occur. In contrast, a plant may benefit more when an herbivore chooses to leave that plant to feed elsewhere. Herbivores that choose to leave damaged plant tissues and disperse their damage often have less adverse effects on plant fitness compared to more aggregated damage (Marquis 1992, Mauricio et al. 1993, Meyer 1998).

A major criticism of behavioral bioassays involving herbivore choice is the artificial confinement of the focal herbivore. Indeed, there are examples demonstrating that an herbivore's preference differed under laboratory, choice test conditions compared to open field studies (Louda and O'Brien 2002; Arnett and Louda 2002). We found that beetle preferences in our bioassays were in agreement with previous work examining plant-to-plant communication and induced resistance in sagebrush that quantified natural patterns of herbivory in the field, with T. pilosa being among the herbivores naturally present (Karban et al. 2006). These findings suggest that beetle feeding decisions between control and experimentally induced leaves were not strongly affected by the artificial conditions imposed by our bioassay.

In conclusion, these results indicate that $T$. pilosa larvae exhibit informed herbivore movement sensu Rubin et al. (2015), meaning that they avoid previously damaged plant tissue. This behavior can have strong effects on the distribution of damage, the consequences of this damage for the host plant, and the performance and abundance of the herbivores (Rubin et al. 2015).

Acknowledgements Open access funding provided by University of Eastern Finland (UEF) including Kuopio University Hospital. This research was in part conducted at the UC Berkeley Sagehen Creek Field Station and we thank Jeff Brown facilitating our work there. This work was supported the EU Horizon 2020 Research and Innovation Program under Marie Sklodowska Curie Grant 797898.

Open Access This article is licensed under a Creative Commons Attribution 4.0 International License, which permits use, sharing, adaptation, distribution and reproduction in any medium or format, as long as you give appropriate credit to the original author(s) and the source, provide a link to the Creative Commons licence, and indicate if changes were made. The images or other third party material in this article are included in the article's Creative Commons licence, unless indicated otherwise in a credit line to the material. If material is not included in the article's Creative Commons licence and your intended use is not permitted by statutory regulation or exceeds the permitted use, you will need to obtain permission directly from the copyright holder. To view a copy of this licence, visit http://creativecommons.org/licenses/by/4.0/.

\section{References}

Arnett AE, Louda SM (2002) Re-test of Rhinocyllus conicus host specificity, and the prediction of ecological risk in biological control. Biol Cons 106:251-257

Choh Y, Shimoda T, Ozawa R, Dicke M, Takabayashi J (2004) Exposure of lima bean leaves to volatiles from herbivore-induced conspecific plants results in emission of carnivore attractants: active or passive process? J Chem Ecol 30:1305-1317

Farmer EE, Ryan CA (1990) Interplant communication: airborne methyl jasmonate induces synthesis of proteinase inhibitors in plant leaves. Proc Natl Acad Sci 87:7713-7716

Heil M, Karban R (2010) Explaining evolution of plant communication by airborne signals. Trends Ecol Evol 25:167-144

Herrera CM (2009) Multiplicity in unity. University of Chicago Press, Chicago

Himanen SJ, Blande JD, Klemola T, Pulkkinen J, Heijari J, Holopainen JK (2010) Birch (Betula spp.) leaves adsorb and re-release volatiles specific to neighbouring plants - a mechanism for associational herbivore resistance? New Phytol 186:722-732

Kant MR, Jonckheere W, Knegt B, Lemos F, Liu J, Schimmel BCJ, Villarroel CA, Ataide LMS, Dermauw W, Glas JJ, Egas M, Janssen A, Van Leeuwen T, Schuurink RC, Sabelis MW, Alba JM (2015) Mechanisms and ecological consequences of plant defence induction and suppression in herbivore communities. Ann Bot 115:1015-1051

Karban R (2011) The ecology and evolution of induced resistance against herbivores. Funct Ecol 25:339-347

Karban R, Baldwin IT (1997) Induced responses to herbivory. University of Chicago Press, Chicago 
Karban R, Baldwin IT, Baxter KJ, Laue G, Felton GW (2000) Communication between plants: induced resistance in wild tobacco plants following clipping of neighboring sagebrush. Oecologia 125:66-71

Karban R, Shiojiri K, Huntzinger M, McCall AC (2006) Damageinduced resistance in sagebrush: volatiles are key to intra- and interplant communication. Ecology 87:922-930

Karban R, Yang LH, Edwards KF (2014) Volatile communication between plants that affects herbivory: a meta-analysis. Ecol Lett 17:44-52

Louda SM, O'Brien CW (2002) Unexpected ecological effects of distributing the exotic weevil, Larinus planus (F.), for the biological control of Canada thistle. Conserv Biol 16:717-727

Pringle WL (1960) The effect of a leaf feeding beetle on big sagebrush in British Columbia. Rangel Ecol Manag 13:139-142

Rubin IN, Ellner SP, Kessler A, Morrell KA (2015) Informed herbivore movement and interplant communication determine the effects of induced resistance in an individual-based model. $\mathrm{J}$ Anim Ecol 84:1273-1285

Shiojiri K, Karban R (2008) Seasonality of herbivory and communication between individuals of sagebrush. Arthropod-Plant Interact 2:87-92

Sugimoto K, Matsui K, Iijima Y, Akakabe Y, Muramoto S, Ozawa R, Uefune M, Sasaki R, Alamgir KM, Akitake S, Nobuke T, Galis I, Aoki K, Shibata D, Takabayashi J (2014) Intake and transformation to a glycoside of (Z)-3-hexenol from infested neighbors reveals a mode of plant odor reception and defense. Proc Natl Acad Sci USA 111:7144-7149

Uesugi A, Poelman EH, Kessler A (2013) A test of genotypic variation in specificity of herbivore-induced responses in Solidago altissima L. (Asteraceae). Oecologia 1:1387-1396

Van Dam NM, Hermenau U, Baldwin IT (2001) Instar-specific sensitivity of specialist Manduca sexta larvae to induced defences in their host plant Nicotiana attenuata. Ecol Entomol 26:578-586

War AR, Paulraj MG, Ahmad T, Buhroo AA, Hussain B, Ignacimuthu S, Sharma HC (2012) Mechanisms of plant defense against insect herbivores. Plant Signal Behav 7:1306-1320

Wiens JA, Cates RG, Rotenberry JT, Cobb N, Van Horne B, Redak RA (1991) arthropod dynamics on sagebrush (Artemisia Tridentata): effects of plant chemistry and avian predation. Ecol Monogr 61:299-322

Young JA, Evans RA, Major J (1988) Sagebrush steppe. In: Barbour MG, Major J (eds) Terrestrial Vegetation of California, 2nd edn edn. California Native Plant Society, Sacramento, pp 763-769

Publisher's Note Springer Nature remains neutral with regard to jurisdictional claims in published maps and institutional affiliations. 